\title{
INNOVATIVE METHODOLOGICAL MODEL OF INSTRUMENTAL PREPARA- TION OF FUTURE TEACHERS OF MUSICAL ART IN THE ASPECT OF DEVEL- OPMENT OF THEIR PERFORMING INDEPENDENCE
}

\author{
V. Burnazova
}

Розглянуто розвиток виконавської самостійності майбутніх учителів музичного мистецтва як не вродженої, а набутої інтегральної властивості особистості, щяо сприяе високій результативності відтворення необхідної інформації на основі творчого втілення у процес інструментальної діяльності сформованої без допомоги ззовні оригінальної інтерпретаційної моделі музичних творів. Пропонується розроблена інновачійна методична модель інструментальної підготовки майбутніх учителів музичного мистеитва в чотирьохфазовому розвитку їх виконавської самостійності, шуо відзначається логічною послідовністю у формуванні й реалізації інтерпретаційної моделі музичних творів.

Перша фаза характеризується спрямуванням зусиль студентів на встановлення внутрішньої організації мотивів та потягів волі до усвідомлення спонукальних дій на отримання об'єктивної інформації щзодо реальної оцінки сценічно-інтерпретаційної складності музичних творів у ході ознайомлення із загальними об 'єктивними та суб'єктивно-творчими ознаками їх текстових та виконавських компонентів музичних творів.

Друга фаза передбачає активізацію прагнень студентів до надання пріоритетного значення процесуальній мотивачїі, яка сприяє максимальній заглибленості у процес усвідомлення музичної інформації, інтеграції та автоматизаџії ігрових рухів з метою конкретизаџії ознак інтерпретаційної моделі музичних творів.

У третій фазі пріоритетного значення набуває спонукання студентів до утримання привабливості установок під час репетиційної реалізації уявної інтерпретаційної моделі музичних творів, утримання привабливості установок і максимальної стійкості уваги на раніше запланованих об'єктивних та суб'єктивно-творчих ознаках текстових і виконавських компонентах музичних творів, а в четвертійорієнтування на закріплення досягнутої виконавської самостійності емоціогенністю умов прилюдної реалізаџії створеної інтерпретаџійної моделі музичних творів. Вона спрямовується на домінування таких форм активності, щз забезпечують призупинення переорієнтації мотивів при їх зіткненні з перешкодами; на уникнення репрезентації старих небажаних мотиваційних утворень; на нівелювання дії екстринсивних мотивів завдяки спрямуванню уваги лише на інтринсивні.

Впровадження відповідної інновачійної методичної моделі в систему інструментальної підготовки майбутніх учителів музичного мистецтва, сприятиме виріменню питань оптимізації напрямків професійної підготовки, стимулювання самозайнятості, шуо безперечно впливає на формування демотивачійних індикаторів щзодо зменшення трудової міграції з Украӥни

Ключові слова: виконавська самостійність, інноваційна методична модель, інструментальна підготовка, учителі музичного мистецтвва

Copyright (C) 2020, V. Burnazova. This is an open access article under the CC BY license (http://creativecommons.org/licenses/by/4.0).

\section{Introduction}

The progressive educational realities of today and the modernization of Ukraine's education system are conditioned by the progressive tendencies of globalization of the European and world educational space, which requires increasing the information and technological level of students' knowledge, equipping them with a complex of both academic qualitative knowledge and the latest science-intensive technologies. Higher education institutions play a major role in these transformations, which should shape the generation of new pedagogical staff, competitive, ready for mobility, original problem solving, rapid processing of a large amount of educational information, through the introduction of European educational standards in the educational and integration process, raising the educational standards. The educational level of future graduates is providing them with modern more effective innovative teaching technologies. The high requirements for the quality of professional training of teachers of music art necessitate the creation and implementation of an updated system of instrumental training of students of the faculties of arts of pedagogical universities, where such phenomenon as performing independence occupies a special place.

\section{Literary review}

The instrumental training of students of the faculties of arts of pedagogical universities requires them to perform independently, both during the formation of the interpretative model of musical works and in the process of its public realization. The works of outstanding artists of music art substantiate theoretical and methodological approaches to solving various technical and interpretative tasks and trace ideas about the purposeful development 
of performing independence, where the interpretive orientation and the formation of professional qualities are dialectically combined. Thanks to the interpretive orientation, there is brought up:

- the creative attitude to the process of activity [1];

- the need for stage expression through the realization of an individually created concept of a sound model of musical works [2, 3];

- the feeling of emotional and sound influence on the listeners [4-6].

In the process of mastering professional and performance qualities, the sensory-perceptual and emotional-volitional spheres of the instrumentalists' activity are improved, as well as the artistry (stage reincarnation, communicative, regulatory, demonstrative and sensomotor stage movements).

Of course, self-development of their performing autonomy is carried out on the basis of knowledge, divided into general (musical-educational, musicalcultural) and special (musical-theoretical, musicalhistorical, musical-performing and musicalpsychological), abilities and skills (communicative, perceptual, motor) $[2,4]$.

The most extensive range of principles for the development of performing independence in future music teachers during the instrumental training is associated with the formation of technical skills of playing the piano and mastering musical material [7].

According to the scholars and prominent artists of musical art [8], the development of this phenomenon is achieved not only by working out different variants of their interpretation, but also by changing the scale of the sound while maintaining the "jewelry" intonation of the melodic-rhythmic line in a flexible dynamic. They put forward the thesis that the process of mastering the material is characterized by a phased or complete work on the musical works. Of course, such a distinction is conditional, so different interpretations of the separation of quantitative components of this process and their content can be traced in the theory and methodology of musical training.

In the psychological plane, the phenomenology of instrumentalists' music-performing is considered in the aspects of emotional response to music, will, attention, memory, imagination, thinking, motivation, as well as their interrelation with auditory, visual, motor representations and processes of awareness and intuition. Investigating the structural components of musical works as an acoustic phenomenon, the American scientist E. H. Margulis considered them based on the indicators of the emotional response of the listeners to the repetition of the musical material. Focusing on the multiple repetition of sounds of the same height, the scientist proves that there are no identical associations, thus asserting the dynamic development of the process of sound in the temporal space [9].

In our opinion, the achievements of psychological science from all the above psychological aspects of studying the phenomenology of instrumentalists' performing activities are not yet fully utilized. In particular, a number of baseline provisions regarding the effect of motivation on performance have not been embodied. Their analysis helps to identify the foundations of the development of performing arts students' artistic autonomy in the process of instrumental preparation, because motivation is characterized not as a mechanical combination of purpose with motives, but as a product of the reflected processes, initiated by the needs, desires and aspirations of their motivators [10].

\section{The purpose and objectives of the study}

The purpose of this article is to shed light on an innovative methodological model of instrumental training of a future music teacher in the aspect of developing their performing independence.

To achieve this goal, it was necessary to solve such problems as:

1) to analyze the state of development of performing independence in the process of instrumental training of future teachers of music in scientific and methodological literature;

2) to cover the content of executive autonomy in the light of modern scientific researches;

3) to reveal the specifics of the purposeful development of the independence of the performing arts of future music teachers in the process of instrumental preparation.

4) to generalize the material on introduction of an innovative step-by-step substantiated model of instrumental training of the future teachers of musical art in aspect of development of their performing independence, which practical application will promote the decision of questions of optimization of directions of vocational training, stimulation of self-employment, certainly should influence the reduction of labor migration from Ukraine.

\section{Materials and methods}

Achieving the goal required the use of research methods that were consistent with the nature of the phenomenon studied, and were adequate to the task, namely:

- analysis of scientific literature within the limits of the studied problem;

- modeling the content of the initial provisions of psychological and pedagogical research into the theory and methodology of instrumental training of future music teachers;

- generalization of the results, obtained in the process of diagnosing the success of instrumental training of future music teachers.

- introduction of an appropriate innovative methodological model in the system of instrumental training of future music teachers to address the issues of optimization of vocational training, stimulation of selfemployment in order to form demotivation indicators for reducing labor migration from Ukraine.

\section{Results of the study and discussion}

Innovation in higher education is becoming more widespread today and is being implemented through the application of new ideas, the consistent introduction of innovative models and learning technologies. Important aspects of pedagogical innovation are reflected in the works of domestic scientists $[8,10]$. However, the problem of instrumental and performing training of future music teachers on technological and innovative grounds deserves special attention. 
On the basis of the theoretical analysis of the scientific literature on the problem under study, the dependence of the performance of the instrumentalists' performance on the quality of the interpretative model of musical works in their imagination is established $[4,8]$. It is proved, that the high quality of education of such a model is ensured by the executive autonomy of the personality, the components of which are self-esteem, self-control, self-correction of perceived information and its systematization through deep mental processing in the absence of direct constant external control.

In pedagogical practice it is defined, that modern innovative educational processes occur in three main directions: change of the system of activity, its functions and hierarchical structure in the process of formation of a personal style of work; a change in the personality of the subject, manifested both in external features (motility, musical language, emotionality, etc.), and in internal formation of the relevant elements of professional consciousness (memory, thinking, etc.), the development of a professional outlook; change of the relevant components of the subject's installation with respect to the object of activity, which manifests itself in the cognitive sphere as raising the level of awareness of the object, in emotional - as interest in interaction with the object, in practical - as awareness of the real possibilities of change in the object.

The development of performing independence was carried out in accordance with the innovative methodological model of instrumental training of future music teachers and was conditionally divided into four phases, namely:

- the first phase is the development of the independence of the performing arts of future music teachers in the course of acquaintance with the general features of the text and performance components of musical works during the selection of a repertoire;

- the second phase is the development of a marked phenomenon in the process of awareness of musical information, integration and automation of game movements in order to specify the features of the interpretative model of musical works;

- the third phase is the improvement of the performer's independence by the rehearsal of the created interpretive model of musical works;

- the fourth phase is the consolidation of the students' accomplished autonomy by the emotionality of the conditions of public realization of the created interpretive model of musical works [10].

The first phase of the development of instrumental and performing independence of future music teachers is characterized by the establishment of internal organization of motives and trains of will to realize the motivating actions to obtain truthful information, regarding the real assessment of the stage and interpretation complexity of musical works in the process of selection of a repertoire; the dominance of a positive impression of creating attractive facilities, aimed at depreciating neglected alternatives after decision-making; determination of the optimum motivational force during acquaintance with the general features of a text and performance components of musical works in order to intensify the search for as much meaningful, emotional and dynamic creativity in the construction of melodic-rhythmic lines in the intonation-phrase development. Here, priority is given to the influence of positive rather than negative emotions on the intrinsic motivation. This is not only guided by the program requirements, accessibility and learning goals, but also by the wishes of the students themselves. The program includes music they like the most, so selecting a repertoire is a creative, long-lasting and not fussy process. Performers' "love" for each piece of their program is the main source of motivation. When augmented by the motivational impulse, the aesthetic features or complexity of the performance components are given a greater weight.

The second phase of the development of performing independence of future music teachers in the process of instrumental preparation involves giving priority to the procedural motivation, which contributes to the maximum immersion in the process of independent formation of the original interpretive model of musical works; adjusting the motivational force in the process of mastering each piece of complex information and selecting the desired forms of reinforcement of the motivating impulses.

Efforts are directed towards creating positive emotions through the enjoyment of awareness of musical information, reproduction of game movements, their integration and automation in order to specify the features of the interpretive model of musical works, that is, through the very process of play. Modeling text and performance components with minimal "separation" from real-world results, the implementation of which requires little time and effort, as well as repetition of gaming operations in the same way, is an effective way to enjoy the effects achieved. Of course, the need for variability in the reproduction of performing skills requires the flexibility of the instrumentalists' sensory and motor responses. It is ensured by multiple repetitions of game operations in every way. However, the most important thing is the combination of fun with a particular activity.

Equally important for correct decision-making is another strong-willed quality - the endurance of instrumentalist musicians, which slows down and, if necessary, nullifies the negative feelings that hinder the implementation of the decision and violate the traditional selfmastery of future music teachers while playing. The presence of these strong-willed qualities contributes to the development of students' executive independence, as a constant activity, optimism and mobilization readiness become norms and habits of their behavior.

The third phase of the development of the independence of the performing art of future music teachers in the process of instrumental preparation is aimed at improving the already achieved level of this phenomenon. It is a characteristic of maintaining the optimum motivational force during the rehearsal of the imaginary interpretative model of musical works; maintaining the attractiveness of installations and maximizing the sustainability of attention to previously planned control attributes; avoiding cognitive dissonance by making bold decisions by updating only automated music and game movements.

Maintaining the optimal motivational force is ensured by the implementation of the developed methods of reproducing the interpretative model of musical works in 
the previously established sequence of a concert program. Such consistency is determined by the requirements and traditions of the future reporting form, the ease of execution of each work in the overall conceptual presentation of the program and the dynamism of perception. It is also taken into account that the adaptation period usually coincides with the beginning of the performance. Under these circumstances, the program first includes intellectually-complicated works or those works that have a deep emotional-figurative content, since the sensory sphere of instrumentalists is less exposed to the stimuli of emotional conditions than motor. Virtuosotechnical works are included in the program at the end of the performance [8].

The purpose of the fourth phase of the development of the future independence of future teachers of music in the process of instrumental preparation is to consolidate its achieved level of emotionality of the conditions of public realization of the created interpretive model of musical works. It aims at the dominance of such forms of activity that ensure the suspension of the reorientation of motives, when they encounter obstacles; to avoid the representation of old unwanted motivational entities; to counteract the effects of extrinsic motives by focusing only on the intrinsic; to ignore thoughts about social and material rewards for the performance of stage activity. One of the peculiarities of this phase of the executive independence development is, as a rule, the lowering of the strength of the initial motivation.

At the end of public speeches, students discuss the effectiveness of their efforts to create the desired motivational force. Here the priority is given to the consolidation of the achieved executive independence due to the positive emotional reinforcement of the motivational force.

Thus, as a result of the research, we demonstrated a new conceptual and methodological approach to solving the problem of the development of the future independence of future teachers of music art in the process of instrumental preparation by the means of regulating the motivational force, while working on musical works and their performance. The methods and techniques of creating an interpretative model of musical works and its realization have been further developed.

The practical significance of the study is determined by the implementation of the developed innovative methodological model of the executive independence development in the process of instrumental training of students of art faculties of higher pedagogical educational institutions. Research materials and findings can be used in other areas of professionals' creative work, based on the specific nature of the activity, and to create an inter-industry platform for professional discussion and exchange of best practices in order to build a network of teachers, ready to innovate, translate changes and share effective practices for improving teaching institutions of higher education of Ukraine and preventing labor migration.

Prospects for further research. Of course, the information presented does not seek to fully disclose all aspects of the problem. They can serve as a basis for further search for effective methods and techniques for the development of the performing independence of students of art faculties of higher educational institutions, not only of pedagogical, but also of musical orientation, since the issues of formation of spatio-temporal features of the interpretative model of musical works, automation of play and automation of musical works have remained poorly understood, regulation of the process of their reproduction, etc.

\section{Conclusions}

Summarizing the above material on the consideration of the sequence of implementation of the innovative step-by-step grounded methodology for the development of the future independence of a future music teacher in the process of instrumental preparation, we can draw conclusions.

1. The process of developing students' performing autonomy during the instrumental preparation is conditionally divided into four phases, which are distinguished by a logical sequence in the formation and implementation of an interpretative model of musical works.

2. The first phase of the development of the executive independence of future music teachers is characterized by the establishment of an internal organization of motives and trains of will to realize the incentive actions to obtain truthful information, regarding the real assessment of the stage-interpretive complexity of musical works in the course of acquaintance with the common objective and subjective works; signs of text and performance components of musical works; the dominance of a positive impression of creating attractive facilities, aimed at depreciating neglected alternatives after making decisions; determining the optimal motivational force in order to activate the search for as much content, emotional and dynamic creativity as possible in the construction of melodic-rhythmic lines in the intonation-phrase development.

3. The second phase of the development of students' performing independence during the instrumental preparation involves giving priority to the procedural motivation, which contributes to the maximum immersion in the process of independent formation of the original interpretive model of musical works; adjusting the motivational force in the process of mastering each piece of complex information and selecting the desired forms of reinforcement of the motivating impulses.

4. The third phase of the development of the independence of the performing arts of future music teachers in the process of instrumental preparation is directed to improving the already achieved level of the identified phenomenon. It is a characteristic of maintaining the optimum motivational force during the rehearsal of the imaginary interpretative model of musical works; maintaining the attractiveness of installations and maximizing the sustainability of attention to the previously planned objective and subjective-creative features of a text and performance components of musical works; avoiding the cognitive dissonance by making bold decisions by updating only automated music and game movements.

5. The fourth phase of the development of the artistic independence of students of artistic faculties in the process of instrumental preparation is characterized by the consolidation of its achieved level of emotionality of the conditions of public realization of the created inter- 
pretive model of musical works. It aims at the dominance of such forms of activity that ensure the suspension of the reorientation of motives, when they encounter obstacles; to avoid the representation of old unwanted motivational entities; to counteract the effects of extrinsic motives by focusing only on the intrinsic; to ignore thoughts about social and material rewards for the performance of stage activity.

6. It is worth noting, that the introduction of the step-by-step methodological model for the development of the future independence of a future music teacher in the process of instrumental training has proved its effectiveness and innovativeness in the educational process of pedagogical institutions of higher education. It also helped to solve the main objective of the Lifelong Learning Program - to reduce the most significant negative effects of labor migration, among which, in our opinion, the cultural orientation with the lack of opportunity to exchange the acquired professional competencies of an instrumentalist musician among representatives of national education, science, culture arts, reducing the professional level of their instrumental training in connection with emigration to foreign countries. It should be remembered, that instrumental and performing skills, in addition to the professional experience, also affect the level of qualification of domestic specialists in foreign countries. Adapting to the current conditions of work and life in foreign countries requires a certain period of time, appropriate psychological and vocational training from a migrant worker. Cases, when domestic specialists, without the ability to adapt to the new environment, find themselves in a difficult position, which causes international specialists to question the skills, professionalism and abilities of this specialist, which in turn affects the quality of professional activity, its productivity and psychological state of a labor migrant, are frequent.

\section{References}

1. Cypin G. M. Obuchenie igre na fortepiano: textbook. Moscow: Enlightenment, 1984. 173 p.

2. Tsagarelli Yu. A. Psihologiya muzyikalno-ispolnitelskoy deyatelnosti: doctors thesis. Kazan, 1989. 425 p.

3. Yunik T. I. Udoskonalennia metodyky zapamiatovuvannia muzychnoho tekstu yak zasib rozvytku vykonavskoi maisternosti studentiv- pianistiv (na materiali pedvuziv): $\mathrm{PhD}$ thesis. Kyiv, 1996. 238 p. 2009. $338 \mathrm{p}$

4. Yunyk D. G. Vykonavska nadiinist muzykantiv: zmist, struktura i metodyka formuvannia: monograph. Kyiv: DAKKKiM,

5. Elliottm D. J. Musical Creativity (Comments to Praxial Music). URL: http://www.davidelliottmusic.com/praxial-musiceducation/musical-creativity/

6. Kotova L. M. Emotsiina stiikist yak zasib formuvannia instrumentalno-vykonaskoi nadiinosti u studentiv muzychnopedahohichnykh fakultetiv: PhD thesis. Melitopol, 2000. 260 p.

7. Shchapov A. P. Nekotorye voprosy fortepiannoi tekhniki. Moscow: Music, 1968. 216 p.

8. Burnazova V. V. Metodychni zasady rozvytku vykonavskoi samostiinosti studentiv muzychno-pedahohichnykh fakultetiv u protsesi instrumentalnoi pidhotovky: PhD thesis. Berdyansk, 2010. $235 \mathrm{p}$.

9. Margulis E. H. Musical Repetition Detection Across Multiple Exposures // Music Perception: An Interdisciplinary Journal. 2012. Vol. 29, Issue 4. P. 377-385. doi: http://doi.org/10.1525/mp.2012.29.4.377

10. Burnazova V. V. Vykonavska samostiinist muzykantiv-instrumentalistiv: zmist, struktura i metodyka rozvytku: monograph. Berdyansk: Publisher of BSPU, 2012. 187 p.

Received date 09.12.2019

Accepted date 14.01.2020

Published date 30.01.2020

Vira Burnazova, PhD, Associate Professor, Department of Theory and Methods of Teaching Arts, Berdiansk State Pedagogical Univarsity, Schmidta str., 4, Berdiansk, Zaporizhzhia region, Ukraine, 71100

E-mail: veronik3105@gmail.com 